\title{
Levosimendan and organic protection
}

Escalona-Belmonte Juan J, Rodriguez-Capitán MJ, Guerrero-OrriachJose L*, Ramirez-Fernandez A, Ramirez Aliaga M, Toledo-Medina C, Malo-Manso A, Rubio Navarro M and Cruz Mañas J

Department of Anaesthesia, Hospital Virgen de la Victoria, Málaga, Spain

\section{Introduction}

The use of levosimendan has not only improved the outlook of patients with pump failure, limiting itself to be a good inotropic: it also had as results the extension of its use to the organ protection realm. Numerous articles have been published of levosimendan (the (-) enantiomer of \{(4- (1,4,5,6-tetrahydro-4-methyl-6-oxo-3pyridazinyl) phenyl) hydrazono propanedinitrile), referring to its molecular mechanisms of action and its effects. We have reviewed them in order to clarify ideas and give some general recommendations.

\section{Pharmacokinetics}

Levosimendan is an inotrope and also a vasodilator, and its two fundamental mechanisms of action are the calcium sensitizing effect and its effect on ATP-sensitive potassium channels. We may add to this the phosphodiesterase inhibition, the effects on biomarker and the effects on energy balance [1-3]. Taking all these mechanisms together, as explained below, helps understand its organ-protective character.

Before starting the study of levosimendan we need to understand its long duration, despite its 1 to 1.5 hours term average living. About a $5 \%$ of the drug is converted to the metabolite OR-1855 in the large intestine, and then acetylated in the liver to form the active metabolite OR-1896. This metabolite binds to plasma proteins by $40 \%$ compared to levosimendan which binds up to $98 \%$, which explains why a relatively low total plasma level of the metabolite may evoke clinically significant effects [4]. Moreover this active metabolite has an about 75 to $80 \mathrm{~h}$ elimination life term, allowing cardiovascuar effects to persist up to 7 to 9 days after discontinuation of a 24-hour infusion of levosimendan $[5,6]$. Renal dysfunction has little effect on the drug's final plasma concentration but appears to prolong the elimination term of OR-1896. Liver cirrhosis slightly prolongs the elimination term of levosimendan, although its effect on the metabolism of OR-1896 is unknown $[7,8]$.

\section{Calcium sensitization and lusitropy}

The basis of $\mathrm{Ca}$ sensitizing mechanism is the interaction with the Ca saturated cardiac troponin $\mathrm{C}$, in a hydrophobic region of its $\mathrm{N}$-domain near the so-called D/E linker region [9-11]. Troponins are heterotrimeric complexes consisting of a troponin $\mathrm{T}$ (TnT) anchoring the complex by binding to tropomyosin, a troponin $\mathrm{C}$ (TnC), whose function is to bind to calcium and troponin I (TnI), which is the inhibitory unit. Muscle contraction begins by calcium binding to the TnC altering interaction between TnC and TnI. This causes the inhibitory region of $\mathrm{TnI}$ to detach from acting and bind to $\mathrm{TnC}$ [12]. Levosimendan stabilizes $\mathrm{Ca}$ saturated $\mathrm{TnC}$, allowing a prolonged interaction between $\mathrm{TnC}$ and $\mathrm{TnI}$, thereby promoting contractile force without an increase in the amplitude of intracellular Ca transient $[9,10]$, and without inhibiting ventricular relaxation [13]. An increase in calcium sensitivity should lead to negative lusitropy, but levosimendan does not prolong relaxation time [14]. On the contrary, in patients with left ventricular hypertrophy it exerts a direct positive lusitropic effect as it shortens isovolumic relaxation time and improves left ventricular filling [15-17].

\section{Phosphodiesterase inhibition}

Both levosimendan and OR-1896 are highly selective inhibitors of the phosphodiesterase (PDE) III isoform. Some studies have tried to relate the lusitropic and inotropic effect of levosimendan with cAMP signaling pathway $[18,19]$. However, for a detectable increase in the level of cAMP and consequently intracellular calcium, inhibition of at least two isoforms of PDE is required, preferably PDE III and PDE IV $[20,21]$, and it is clearly demonstrated that nor levosimendan neither its active metabolite affect the function of other PDE isozymes at their therapeutic concentrations [22]. Levosimendan this way, unlike other inotropes, is highly selective for PDE III, and thus allows other intracellular PDE catabolism cAMP to its physiological levels [23]. Higher than therapeutic doses or different species dependent cyclic nucleotide signaling, could explain the results of the above studies, since results of several investigations indicate that alteration in intracellular Ca concentration (resulting from cAMP elevation secondary to PDE inhibition) are not a prerequisite for the cardiac effects of levosimendan [24-26].

\section{Potassium channels and vasodilatation}

Levosimendan- and OR-1896- mediated vasodilatation have been linked in numerous studies to action on different potassium channels in arterial myocytes. This action has involved the opening of these channels, with the consequent outflow of potassium and hyperpolarization of the cell. Different potassium channels have been linked (glibenclamide- sensitive $\mathrm{K}^{+}$channel, voltage-gated $\mathrm{K}^{+}$channels, $\mathrm{Ca}^{2+}$-activated $\mathrm{K}^{+}$channels and ATP-sensitive $\mathrm{K}^{+}$channels) and the proportion thereof depends on the type of blood vessel and also on vascular diameter. Vasodilatation has been demonstrated at the arterial sides of the pulmonary, coronary and peripheral circulations and at the venous sides of the portal and saphenous systems [27-33]. Endothelial mechanisms also have been implicated in vasodilatation with nitric oxide production secondary to the use of levosimendan [34].

Correspondence to: Jose Luis Guerrero Orriach, Hospital Virgen de la Victoria Campus Universitario Teatinos C.P. 29010, Malaga, Spain, Tel: 0034951032217; E-mail: guerreroorriach@terra.com

Received: April 07, 2015; Accepted: May 04, 2015; Published: May 06, 2015 


\section{Mitochondrial ATP-sensitive potassium channels and energy balance}

The cardiac muscle has high energy demand, primarily used for excitation and contraction coupling and force generation. It is necessary, therefore, a proper fit between the production of ATP and the workload without which energy resources quickly drain [35]. We need to know how the heart muscle makes this link and here is where potassium channels, acting as metabolic sensors, seem to play an important role [36-39]. We find this kind of potassium channel formed as heteromultimers of inwardly-rectifying potassium $\mathrm{K}+$ channel (Kir) 6.2 and ATP-Binding Cassette (ABC) Sulfonylurea Receptor (SUR) 2A proteins $[40,41]$. The domain SUR will translate local levels of ADP and ATP, which will depend on ATPases and phosphotransfer reactions, to channel function. In cells where metabolites mobility is limited between their microdomains, reactions of these enzymes acting on potassium channels will translate internal nucleotide levels into changes in membrane excitability, thus achieving a coupling between demand and metabolic reserves [42-44]. The domain SUR through its structure will bind to ATP, having ability to hydrolyze it and convert to ADP, and also will be attached to the Kir domains. When bound to ATP, it translates the potassium channel closure, and when it is already attached to posthydrolytic ADP it translates the channel opening. In situations of stress, we found high levels of ADP, prevailing therefore open channel shape [45]. Thus, in situations of high energy demand the opening of potassium channels adjust the membrane excitability and produces a shortening of the action potential duration, limiting intracellular calcium loading. This will ensure electrical stability and diastolic interval prolongation, getting a suitable differential intracellular calcium concentration between systole and diastole, which is optimal for cardiac relaxation $[37,38,42]$. All this helps us to see how the levosimendan, acting on these receptors, plays a fundamental role in the regulation of energy metabolism, preventing calcium overload of mitochondria and thereby preserving the high-energy phosphates and regulation of mitochondrial volume $[46,47]$. A recent study about the effects of levosimendan on mitochondria in septic shock concludes that it protects the mitochondria of oxidative stress and may thus mitigate the bioenergetic failure, reinforcing the idea of protecting the energy metabolism through action on the ATP-sensitive potassium channels [48].

\section{Biomarkers}

As biomarkers we refer to a series of biological substances that act as markers of stress and myocytes damage. These substances are believed to be related to the pathogenesis and progression of chronic heart failure [1].The elevation of Brain Natriuretic Peptide (BNP) in heart failure has been shown to have a direct relationship with mortality, and levosimendan causes a significant drop in its plasma levels [49,50]. Further still, the greater falling in BNP with the treatment has a better prognosis at six months in the patients who got it [51]. Besides decreasing the BNP, levosimendan gets reduction of other neurohormonal markers such as IL-6 and CRP, both proinflammatory cytokines, and nuclear factor kappa $\mathrm{B}$ (NF-KB), another cytokine which is released in situations of hypoperfusion and has arrithmogenic properties [52,53]. All this suggests an immunomodulatory effect of levosimendan, improving the neurohormonal and inflammatory situation and implicating a potential interference with cardiomyocyte apoptosis and myocardial remodeling, supplementing its vasodilators and inotropic effects [1].

\section{Mechanism of action}

Levosimendan increases the contractile force of the cardiac muscle fibers; causes coronary, arterial and venous vasodilatation and exerts an organprotective effect against ischemia [1].

\section{Brain protection}

Cerebral ischemia activates cellular processes, including apoptosis, inflammation, inhibition of protein synthesis and increased oxidative stress, which persist despite the restoration of substrate delivery [54]. Every minute of lost cerebral perfusion in the human brain results in a loss of neurons that is equivalent to the loss of neurons after 3.6 years of the normal human ageing process [55].

The only valid form of therapy to improve neurological outcome is to perform therapeutic hypothermia 12 to $24 \mathrm{~h}$ following resuscitation [56]. Concomitant with the symptomatic therapy used to achieve return of spontaneous circulation, therapeutic options employed to minimize the reperfusion injury have to be considered [57].

Levosimendan has been shown to be neuroprotective in the spinal cord when applied prior to or during ischemia.

Evidence of levosimendan'sneuroprotective properties include reduced cell death, inflammatory response and lipid peroxidation; besides, improved function after transient ischemia [58,59].

The important role of the mitochondrial ATP dependent potassium channels in cerebral ischaemia-reperfusion injury and positive action of other activators (diazoxide) on neuronal injury create hopes for neuroprotective effects of this drug [60,61].

\section{Kidney protection}

Renal dysfunction is common in patients with heart failure [62] and other clinical settings in which cardiac function is commited $[63,64]$. Due to the complex interactions underlying this cardiorenal syndrome, kidneys can be affected both in the short and long terms [65]. Impaired renal function has impact on the prognosis of patients with compromised heart function [66]. In advanced chronic heart failure, renal impairment was a stronger predictor of mortality than left ventricular ejection fraction or New York Heart Association class [67].

Anti-oxydant and anti-apoptotic effects of levosimendan could be related to protection against renal ischemic reperfusion injury and improvement of renal function in heart failure cases [65]. Treatment with this drug may reverse the on-going processes of renal dysfunction through protective mechanisms involving macro or microcirculation. Renal blood flow depends on renal vascular resistance and arterial and venous pressures. Central venous pressure is an important independent predictor of glomerular filtration rate in patients with heart failure [68].

Levosimendan provides functional improvement of the right ventricle and significant reductions in right-sided pressures, including central venous and pulmonary artery wedge pressures. This alleviates the increased renal vein pressure that may impair renal function through a decreased perfusion pressure and a decrease in glomerular filtration rate [69-71].

This drug induces a preglomerular vasodilatation (increases renal blood flow and glomerular filtrate rate), suggesting that the beneficial renal effects of levosimendan in patients with heart failure and impaired renal function may not only be caused by an increase in cardiac output, but also by a specific renal vasodilator action [72]. ATP 
sensitive potassium channels are also present in afferent arterioles and may play a role in the effects of this drug on renal blood flow [73].

In relation to the microcirculation, levosimendan may augment renal perfusion via vasodilatation arising from its ATP sensitive potassium channel agonism. Additionally, it may reverse angiotensin-2 mediated mesangial cell contraction [74], thereby increasing glomerular capillary surface area [75].

\section{Liver and intestine protection}

Levosimendan increases blood flow in intestine and liver, reducing resistance in these organs. Its effects on the oxygenation of the microvasculature of gastric mucosa are higher than others drugs (dobutamine and milrinone); so we must use it to improve the oxygenation of gastrointestinal mucosa in case with a high risk of splanchnic ischemia [53].

\section{Cardio protection}

The cardioprotective effect has a multifactorial cause:

1. The reduction in preload and afterload improves cardiac work. Levosimendan improves the contractile force during systole without negatively affecting the relaxation during diastole. This leads to higher cardiac contractility without increasing oxygen consumption by the myocardium $[2,15]$.

2. The increase in coronary blood flow improves the perfusion of cardiac cells [76].

Levosimendan protects against ischemic events, is able to reduce the size of the infarcted area and improves cardiac function recovery after global ischemia [77]. For this reason levosimendan pretreatment has been suggested for the prevention of ischemiareperfusion injury in coronary bypass surgery, [78] because myocardial contractility, stroke volume and cardiac output are preserved in spite of the hypoxic insult [79].

Recent studies show its low arrhythmogenic profile because it acts against inflammation and oxidative damage, which are involved in the pathogenesis of arrhythmias [80,81].

Furthermore, it acts against myocardial stunning both ischemic disease and sepsis [82]. Levosimendan improves systemic hemodynamic and regional perfusion in patients with septic cardiac dysfunction [83]. Its inotropic properties are not compromised in the acidotic or hypoxic heart [84]. Acute respiratory distress syndrome is frequently associated with increased pulmonary vascular resistance and systolic load of the right ventricle, which is associated with high morbidity and mortality [85]. Levosimendan, with potential pulmonary vasodilator properties, improves right ventricle performance [86].

Patients undergoing cardiac surgery with a reduced ejection fraction and who received levosimendan before, during, or after surgery presented lower mortality and myocardial injury than other patients. Furthermore, it was reduced the development of postoperative low output syndrome as well as the need for inotropic and vasoactive agents and intra-aortic balloon counter pulsation [87].

The administration of levosimendan facilitates disconnection from CPB thanks to its inotropic and lusitropic effects and reduces the need for mechanical support due to weaning failure and the ICU stay. Markers of tissue oxygenation and myocardial damage (lactate and troponin T) are lower with this drug $[88,89]$.
Levosimendan decreases levels of brain natriuretic peptide. The magnitude of the reduction in brain natriuretic peptide levels caused by levosimendan treatment is correlated with improved clinical outcomes at six month. Brain natriuretic peptide levels can be regarded as a prognostic factor of its effectiveness [90].

Levosimendan alters levels of cardiac biomarkers related to the progression of congestive heart failure; it reduces proinflammatory cytokines, has a favorable effect on markers of oxidative stress and prevents myocardial apoptosis in myocytes [91].

\section{Conclusions}

Levosimendan is an inotropic agent with vasodilator effects, thanks to a triple mechanism of action: sensitizing effect of calcium channels in cardiac myofilaments fibers, opening of ATP-sensitive potassium channels in smooth muscle cells and opening the ATP-sensitive potassium channels in cardiac cells mitochondria. Through this triple mechanism levosimendan increases the contractile force of cardiac muscle fibers, causes both arterial and venous peripheral vasodilation and has a cardioprotective effect against ischemic situations [92].

The increase in the flow of potassium associated with the opening of ATP-sensitive channels of mitochondria seems sufficient to protect and preserve mitochondrial function, mainly through standardizing matrix and the intermembrane space volume under stress as ischemia or reperfusion injury $[93,94]$. It has recently been published a metaanalysis of 14 clinical trials of patients selected for cardiac surgery in which levosimendan was used. Its authors found a significant reduction in mortality in patients having a decreased dejection fraction of the left ventricle.

It were also found decreased postoperative complications in patients to whom the drug was given. There is no evidence however of decreased mortality in patients who develop low cardiac output regardless of previous situation and the mechanism by which this decrease would happen. The reason why levosimendan improves outcomes in cardiac surgery may be related to its ability to improve contractility without increasing oxygen consumption and its ability to recover stunned myocardium. These hemodynamic effects are much greater than with dobutamine and unlike this it is not affected by concomitant use of beta-blockers, as the effect of levosimendan is not dependent on beta-adrenergic receptors. Improvement of stunned myocardium by the rest of catecholamines is based on an increase in intracellular calcium in the myocytes, which in turn leads to an increase in the possibility of arrhythmia and impaired myocardial relaxation. Unlike levosimendan, mechanism has been proposed as part of the apoptosis [95,96]. Besides cardioprotection against ischemic events and stunning effect protection levosimendan may have effects against ischemia in other organs. Neurological complications in the immediate postoperative period of cardiac surgery are a major cause of morbidity and mortality, causing an increase in the use of health resources and leading to functional limitations in those who survive.

In these tables cardiac dysfunction is one of the most important predisposing factors. Recently cognitive impairment has been identified in $83 \%$ of patients undergoing cardiac surgery [97]. At brain level in vitro studies levosimendan has shown its possible neuronal protection during ischemic situations or neuronal hypoperfusion, being able to decrease motor dysfunction due to created spinal cord ischemia [98]. Acute Renal Failure (ARF) is a common complication of cardiovascular surgery, with a reported varying incidence which depends on both the used FRA definition and the studied population, but in most estimates 
close to $30 \%$, reaching values at mortality series between $70 \%$ and $90 \%$ $[99,100]$. There have been several studies on the possible beneficial effect of levosimendan on renal function in postoperative cardiac surgery, noting that of Bragadottir et al., in which an improvement in glomerular filtration rate, renal blood flow and renal oxygenation is observed regardless of the improvement in cardiac function [101]. A recent meta-analysis demonstrated that perioperative administration of levosimendan has beneficial effects at the level of renal function, although the heterogeneity of the studies makes interpretation difficult [30].

We have recently published two articles and an editorial regarding the use of levosimendan in cardiac surgery, showing the cardiac benefit of its administration in patients with ventricular dysfunction and its possible organ protection properties $[53,85]$. New jobs are needed for the evaluation of the promising organ protection role of levosimendan, an inodilator which becomes a perioperative drug having multiorgan conditioning properties.

\section{References}

1. Papp Z, Édes I, Fruhwald S, De Hert SG, Salmenperä M, et al. (2012) Levosimendan: molecular mechanisms and clinical implications: consensus of experts on the mechanisms of action of levosimendan. Int J Cardiol 159: 82-87. [Crossref]

2. Nieminen MS, Pollesello P, Vajda G, Papp Z (2009) Effects of levosimendan on the energy balance: preclinical and clinical evidence. J Cardiovasc Pharmacol 53: 302-310. [Crossref]

3. Parissis JT, Adamopoulos S, Antoniades C, Kostakis G, Rigas A, et al. (2004) Effects of levosimendan on circulating proinflammatory cytokynes and soluble apoptosis mediators in patients with decompensated advanced heart failure. Am J Cardiol 93: 1309-1312. [Crossref]

4. Sandell EP, Hayha M, Antila S, Heikkinen P, Ottoila P, et al. (1995) Pharmacokinetics of levosimendan in healthy volunteers and patients with congestive heart failure. $J$ Cardiovasc Pharmacol 26 Suppl 1: S57-62. [Crossref]

5. Lilleberg J, Laine M, Palkama T, Kivikko M, Pohjanjousi P, et al. (2007) Duration of the haemodynamic action of a 24-h infusion of levosimendan in patients with congestive heart failure. Eur J Heart Fail 9: 75-82. [Crossref]

6. Kivikko M, Antila S, Eha J, Lehtonen L, Pentikäinen PJ (2002) Pharmacokinetics of levosimendan and its metabolites during and after a 24-hour continuous infusion in patients with severe heart failure. Int J Clin Pharmacol Ther 40: 465-471. [Crossref]

7. Cleland JG, McGowan J (2002) Levosimendan: a new era for inodilator therapy for heart failure? Curr Opin Cardiol 17: 257-265. [Crossref]

8. Puttonen J, Kantele S, Ruck A, Ramela M, Häkkinen S, et al. (2008) Pharmacokinetics of intravenous levosimendan and its metabolites in subjects with hepatic impairment. $J$ Clin Pharmacol 48: 445-454. [Crossref]

9. Sorsa T, Pollesello P, Rosevear PR, Drakenberg T, Kilpeläinen I (2004) Stereoselective binding of levosimendan to cardiac troponin $\mathrm{C}$ causes Ca2+-sensitization. Eur $J$ Pharmacol 486: 1-8. [Crossref]

10. Sorsa T, Heikkinen S, Abbott MB, Abusamhadneh E, Laakso T, et al. (2001) Binding of levosimendan, a calcium sensitizer, to cardiac troponin C. J Biol Chem 276: 9337 9343. [Crossref]

11. Robertson IM, Sun YB, Li MX, Sykes BD (2010) A structural and functiona perspective into the mechanism of $\mathrm{Ca} 2+$-sensitizers that target the cardiac troponin complex. J Mol Cell Cardiol 49: 1031-1041. [Crossref]

12. Sorsa T, Pollesello P, Permi P, Drakenberg T, Kilpeläinen I (2003) Interaction of levosimendan with cardiac troponin $\mathrm{C}$ in the presence of cardiac troponin I peptides. $J$ Mol Cell Cardiol 35: 1055-1061. [Crossref]

13. Figgitt DP, Gillies PS, Goa KL (2001) Levosimendan. Drugs 61: 613-627. [Crossref]

14. Haikala H, Nissinen E, Etemadzadeh E, Levijoki J, Lindén IB (1995) Troponin $\mathrm{C}$-mediated calcium sensitization induced by levosimendan does not impair relaxation. J Cardiovasc Pharmacol 25: 794-801. [Crossref]

15. Jörgensen K1, Bech-Hanssen O, Houltz E, Ricksten SE (2008) Effects of levosimendan on left ventricular relaxation and early ?lling at maintained preload and afterload conditions after aortic valve replacement for aortic stenosis. Circulation 117: 10751081. [Crossref]

16. Janssen PM, Datz N, Zeitz O, Hasenfuss G (2000) Levosimendan improves diastolic and systolic function in failing human myocardium. Eur J Pharmacol 404: 191-199. [Crossref]

17. Givertz MM, Andreou C, Conrad CH, Colucci WS (2007) Direct myocardial effects of levosimendan in humans with left ventricular dysfunction: alteration of force-frequency and relaxtion-frequency relationships. Circulation 115: 1218-1224. [Crossref]

18. Takahashi R, Talukder MA, Endoh M (2000) Effects of OR-1896, an active metabolite of levosimendan, on contractile force and aequorin light transients in intact rabbit ventricular myocardium. J Cardiovasc Pharmacol 36: 118-125. [Crossref]

19. Bokník P, Neumann J, Kaspareit G, Schmitz W, Scholz H, et al. (1997) Mechanisms of the contractile effects of levosimendan in the mammalian heart. J Pharmacol Exp Ther 280: 277-283. [Crossref]

20. Mongillo M, McSorley T, Evellin S, Sood A, Lissandron V, et al. (2004) Fluorescence resonance energy transfer-based analysis of cAMP dynamics in live neonatal rat cardiac myocytes reveals distinct functions of compartmentalized phosphodiesterases. Circ Res 95: 67-75. [Crossref]

21. Kelso EJ, McDermott BJ, Silke B (1995) Actions of the novel vasodilator, flosequinan, in isolated ventricular cardiomyocytes. J Cardiovasc Pharmacol 25: 376-386. [Crossref]

22. Szilágyi S, Pollesello P, Levijoki J, Kaheinen P, Haikala H, et al. (2004) The effects of levosimendan and OR-1896 on isolated hearts, myocyte-sized preparations and phosphodiesterase enzymes of the guinea pig. Eur J Pharmacol 486: 67-74. [Crossref]

23. Szilágyi S, Pollesello P, Levijoki J, Haikala H, Bak I, et al. (2005) Two inotropes with different mechanisms of action: contractile, PDE-inhibitory and direct myofibrillar effects of levosimendan and enoximone. J Cardiovasc Pharmacol 46: 369-376. [Crossref]

24. Lancaster MK, Cook SJ (1997) The effects of levosimendan on [Ca2+]i in guinea-pig isolated ventricular myocytes. Eur J Pharmacol 339: 97-100. [Crossref]

25. Hasenfuss G, Pieske B, Castell M, Kretschmann B, Maier LS, et al. (1998) Influence of the novel inotropic agent levosimendan on isometric tension and calcium cycling in failing human myocardium. Circulation 98: 2141-2147. [Crossref]

26. Haikala H, Kaheinen P, Levijoki J, Lindén IB (1997) The role of cAMP- and cGMPdependent protein kinases in the cardiac actions of the new calcium sensitizer levosimendan. Cardiovasc Res 34: 536-546. [Crossref]

27. Yokoshiki H, Katsube Y, Sunagawa M, Sperelakis N (1997) Levosimendan, a nove $\mathrm{Ca} 2+$ sensitizer, activates the glibenclamide-sensitive $\mathrm{K}+$ channel in rat arterial myocytes. Eur J Pharmacol 333: 249-259. [Crossref]

28. Yildiz O (2007) Vasodilating mechanisms of levosimendan: involvement of $\mathrm{K}^{+}$ channels. J Pharmacol Sci 104: 1-5. [Crossref]

29. Erdei N, Papp Z, Pollesello P, Edes I, Bagi Z (2006) The levosimendan metabolite OR1896 elicits vasodilation by activating the $\mathrm{K}(\mathrm{ATP})$ and $\mathrm{BK}(\mathrm{Ca})$ channels in rat isolated arterioles. Br J Pharmacol 148: 696-702. [Crossref]

30. Yokoshiki H, Katsube Y, Sunagawa M, Sperelakis N (1997) The novel calcium sensitizer levosimendan activates the ATP-sensitive $\mathrm{K}+$ channel in rat ventricular cells. J Pharmacol Exp Ther 283: 375-383. [Crossref]

31. Pataricza J, Krassói I, Höhn J, Kun A, Papp JG (2003) Functional role of potassium channels in the vasodilating mechanism of levosimendan in porcine isolated coronary artery. Cardiovasc Drugs Ther 17: 115-121. [Crossref]

32. Höhn J, Pataricza J, Petri A, Tóth GK, Balogh A, et al. (2004) Levosimendan interacts with potassium channel blockers in human saphenous veins. Basic Clin Pharmacol Toxicol 94: 271-273. [Crossref]

33. De Witt BJ, Ibrahim IN, Bayer E, Fields AM, Richards TA, et al. (2002) An analysis of responses to levosimendan in the pulmonary vascular bed of the cat. Anesth Analg 94: 1427-1433. [Crossref]

34. Grossini E, Molinari C, Caimmi PP, Uberti F, Vacca G (2009) Levosimendan induce NO production through p38 MAPK, ERK and Akt in porcine coronary endothelial cells: role for mitochondrial K(ATP) channel. Br J Pharmacol 156: 250-261. [Crossref]

35. Balaban RS (2005) Cardiac energy metabolism homeostasis: role of cytosolic calcium J Mol Cell Cardiol 3: 895-905. [Crossref]

36. Selivanov V, Alekseev AE, Hodgson DM, Dzeja PP, Terzic A (2004) Nucleotide-gated 
KATP channels integrated with creatine and adenylate kinases: ampli?cation, tuning and sensing of energetic signals in the compartmentalized cellular environment. $\mathrm{Mol}$ Cell Biochem 256: 243-256. [Crossref]

37. Seino S, Miki T (2003) Physiological and pathophysiological roles of ATP-sensitive K+ channels. Prog Biophys Mol Biol 81: 133-176. [Crossref]

38. Zingman LV, Hodgson DM, Bast PH, Kane GC, Perez-Terzic C, et al. (2002) Kir6.2 is required for adaptation to stress. Proc Natl Acad Sci U S A 99: 13278-13283. [Crossref]

39. Zingman LV, Hodgson DM, Alekseev AE, Terzic A (2003) Stress without distress: homeostatic role for K(ATP) channels. Mol Psychiatry 8: 253-254. [Crossref]

40. Inagaki N, Gonoi T, Clement JP 4th, Namba N, Inazawa J, et al. (1995) Reconstitution of IKATP: an inward rectifier subunit plus the sulfonylurea receptor. Science 270: 11661170. [Crossref]

41. John SA, Weiss JN, Ribalet B (2001) Regulation of cloned ATP-sensitive K channels by adenine nucleotides and sulfonylureas: interactions between SUR1 and positively charged domains on Kir6.2. J Gen Physiol 118: 391-405. [Crossref]

42. Zingman LV, Alekseev AE, Hodgson-Zingman DM, Terzic A (2007) ATP-sensitive potassium channels: metabolic sensing and cardioprotection. J Appl Physiol (1985) 103: 1888-1893. [Crossref]

43. Abraham MR, Selivanov VA, Hodgson DM, Pucar D, Zingman LV, et al. (2002) Coupling of cell energetics with membrane metabolic sensing. Integrative signaling through creatine kinase phosphotransfer disrupted by M-CK gene knockout. $J$ Biol Chem 277: 24427-24434. [Crossref]

44. Alekseev AE, Hodgson DM, Karger AB, Park S, Zingman LV, et al. (2005) ATPsensitive $\mathrm{K}+$ channel channel/enzyme multimer: metabolic gating in the heart. $J \mathrm{Mol}$ Cell Cardiol 38: 895-905. [Crossref]

45. Zingman LV, Alekseev AE, Bienengraeber M, Hodgson D, Karger AB, et al. (2001) Signaling in channel/enzyme multimers: ATPase transitions in SUR module gate ATPsensitive K+ conductance. Neuron 31: 233-245. [Crossref]

46. Toller WG, Stranz C (2006) Levosimendan, a new inotropic and vasodilator agent. Anesthesiology 104: 556-569. [Crossref]

47. Gross GJ, Peart JN (2003) KATP channels and myocardial preconditioning: an update. Am J Physiol Heart Circ Physiol 285: H921-930. [Crossref]

48. Torraco A, Carrozzo R, Piemonte F, Pastore A2, Tozzi G, et al. (2014) Effects of levosimendan on mitochondrial function in patients with septic shock: a randomized trial. Biochimie 102: 166-173. [Crossref]

49. Cohen-Solal A, Logeart D, Huang B, Cai D, Nieminen MS, et al. (2009) Lowered B-type natriuretic peptide in response to levosimendan or dobutamine treatment is associated with improved survival in patients with severe acutely decompensated heart failure. J Am Coll Cardiol 53: 2343-2348. [Crossref]

50. Kyrzopoulos S, Adamopoulos S, Parissis JT, Rassias J, Kostakis G, et al. (2005) Levosimendan reduces plasma B-type natriuretic peptide and interleukin 6 , and improves central hemodynamics in severe heart failure patients. Int J Cardiol 99: 409413. [Crossref]

51. Giannakoulas G, Giannoglou G, Vassilikos V, Martiadou K, Kalpidis P, et al. (2006) Clinical significance of acute neurohormonal response after levosimendan treatment. Am J Cardiol 98: 1123-1124. [Crossref]

52. Adamopoulos S, Parissis JT, Iliodromitis EK, Paraskevaidis I, Tsiapras D, et al. (2006) Effects of levosimendan versus dobutamine on inflammatory and apoptotic pathways in acutely decompensated chronic heart failure. Am J Cardiol 98: 102-106. [Crossref]

53. Orriach Guerrero JL, Ramirez Fernandez A, Iglesias P, Galan M, Melero JM, et al. (2014) Preoperative levosimendan. A new way for organoprotection. Curr Pharm Des 20: 5476-5483. [Crossref]

54. Fukuda S, Warner DS (2007) Cerebral protection. Br J Anaesth 99: 10-17. [Crossref]

55. Saver JL (2006) Time is brain--quantified. Stroke 37: 263-266. [Crossref]

56. Bernard S (2009) Hypothermia after cardiac arrest: expanding the therapeutic scope. Crit Care Med 37: S227-233. [Crossref]

57. Roehl AB, Zoremba N, Kipp M, Schiefer J, Goetzenich A, et al. (2012) The effects of levosimendan on brain metabolism during initial recovery from global transient ischaemia/hypoxia. BMC Neurol 12: 81. [Crossref]

58. Katircioglu SF, Seren M, Parlar AI, Turan NN, Manavbasi Y, et al. (2008) Levosimendan effect on spinal cord ischemia-reperfusion injury following aortic clamping. $J$ Card Surg 23: 44-48. [Crossref]
59. Lafci B, Yasa H, Ilhan G, Ortac R, Yilik L, et al. (2008) Protection of the spinal cord from ischemia: comparative effects of levosimendan and iloprost. Eur Surg Res 41: 1-7. [Crossref]

60. Mayanagi K, Gaspar T, Katakam PV, Busija DW (2007) Systemic administration of diazoxide induces delayed preconditioning against transient focal cerebral ischemia in rats. Brain Res 1168: 106-111. [Crossref]

61. Bantel C, Maze M, Trapp S (2009) Neuronal preconditioning by inhalational anesthetics: evidence for the role of plasmalemmal adenosine triphosphate-sensitive potassium channels. Anesthesiology 110: 986-995. [Crossref]

62. Metra M, Cotter G, Gheorghiade M, Dei Cas L, Voors AA (2012) The role of the kidney in heart failure. Eur Heart $J 33:$ 2135-2142. [Crossref]

63. Kallel S, Triki Z, Abdenadher M, Frikha I, Jemel A, et al. (2013) Acute renal failure after cardiac surgery: evaluation of the RIFLE criteria. Nephrol Ther 9: 108-114. [Crossref]

64. Oppert M, Engel C, Brunkhorst F-M, Bogatsch H, Reinhart K, et al. (2008) Acute renal failure in patients with severe sepsis and septic shock-a significant independent risk factor for mortality: results from the German Prevalence Study. Nephrol Dial Transplant 23: 904-909. [Crossref]

65. Yilmaz MB, Grossini E, Silva Cardoso JC, Édes I, Fedele F, et al. (2013) Renal effect of levosimendan: a consensus report. Cardiovasc Drugs Ther 27: 581-590. [Crossref]

66. Hillege HL, Nitsch D, Pfeffer MA, Swedberg K, McMurray JJ, et al. (2006) Renal function as a predictor of outcome in a broad spectrum of patients with heart failure. Circulation 113: 671-678. [Crossref]

67. Hillege HL, Girbes AR, de Kam PJ, Boomsma F, de Zeeuw D, et al. (2000) Rena function, neurohormonal activation, and survival in patients with chronic heart failure. Circulation 102: 203-210. [Crossref]

68. Damman K, van Deursen VM, Navis G, Voors AA, van Veldhuisen DJ, et al. (2009) Increased central venous pressure is associated with impaired renal function and mortality in a broad spectrum of patients with cardiovascular disease. $J$ Am Coll Cardiol 53: 582-588. [Crossref]

69. Parissis JT, Paraskevaidis I, Bistola V, Farmakis D, Panou F, et al. (2006) Effects of levosimendan on right ventricular function in patients with advanced heart failure. $\mathrm{Am}$ J Cardiol 98: 1489-1492. [Crossref]

70. Poelzl G, Zwick RH, Grander W, Metzler B, Jonetzko P, et al. (2008) Safety and effectiveness of levosimendan in patients with predominant right heart failure. Herz 33: 368-373. [Crossref]

71. Russ MA, Prondzinsky R, Carter JM, Schlitt A, Ebelt H, et al. (2009) Right ventricular function in myocardial infarction complicated by cardiogenic shock: improvement with levosimendan. Crit Care Med 37: 3017-3023. [Crossref]

72. Bragadottir G, Redfors B, Ricksten SE. Effects of levosimendan on renal blood flow, glomerular filtration rate, renal oxygen consumption and oxygenation after cardiac surgery: a randomized controlled study. Crit Care Med, In press.

73. Lorenz JN, Schnermann J, Brosius FC, Briggs JP, Furspan PB (1992) Intracellular ATP can regulate afferent arteriolar tone via ATP-sensitive $\mathrm{K}+$ channels in the rabbit. $J$ Clin Invest 90: 733-740. [Crossref]

74. Zager RA, Johnson AC, Lund S, Hanson SY, Abrass CK (2006) Levosimendan protects against experimental endotoxemic acute renal failure. Am J Physiol Renal Physiol 290 F1453-1462. [Crossref]

75. Appel RG, Wang J, Simonson MS, Dunn MJ (1986) A mechanism by which atrial natriuretic factor mediates its glomerular actions. Am J Physiol 251: F1036-1042. [Crossref]

76. Du Toit EF, Genis A, Pollesello P (2007) Levosimendan, a new antifailure inodilator, has cardioprotective properties mediated by mitochondrialK-ATP channels. $J \mathrm{Mol}$ Cell Cardiol 5: 257-263.

77. Morelli A, De Castro S, Teboul JL, Singer M, Rocco M, et al. (2005) Effects of levosimendan on systemic and regional hemodynamics in septic myocardial depression. Intensive Care Med 31: 638-644. [Crossref]

78. Tritapepe L, De Santis V, Vitale D, Guarracino F, Pellegrini F, et al. (2009) Levosimendan pre-treatment improves outcomes in patients undergoing coronary artery bypass graft surgery. Br J Anaesth 102: 198-204. [Crossref]

79. Schwarte LA, Schwartges I, Thomas K, Schober P, Picker O (2011) The effects of levosimendan and glibenclamide on circulatory and metabolic variables in a canine model of acute hypoxia. Intensive Care Med 37: 701-710. [Crossref] 
80. Kowalczyk M, Banach M, Lip GY, KozÅ,owski D, Mikhailidis DP, et al. (2010) Levosimendan - a calcium sensitising agent with potential anti-arrhythmic properties. Int J Clin Pract 64: 1148-1154. [Crossref]

81. Follath F, Cleland JG, Just H, Papp JG, Scholz H, et al. (2002) Steering Committee and Investigators of the Levosimendan Infusion versus Dobutamine (LIDO) Study (2002) Efficacy and safety of intravenous levosimendan compared with dobutamine in severe low-output heart failure (the LIDO study): a randomised double-blind trial. Lancet 360: 196-202. [Crossref]

82. Morelli A, Teboul JL, Maggiore SM, Viellard-Baron A, Rocco M, et al. (2006) Effects oflevosimendan on right ventricular afterload in patients with acute respiratory distress syndrome: a pilot study. Crit Care Med 34: 2287-2293. [Crossref]

83. Morelli A, De Castro S, Teboul JL, Singer M, Rocco M, et al. (2005) Effects of levosimendan on systemic and regional hemodynamics in septic myocardial depression. Intensive Care Med 31: 638-644. [Crossref]

84. Endoh M (2008) Cardiac Ca2+ signaling and Ca2+ sensitizers. Circ J 72: 1915-1925. [Crossref]

85. Guerrero-Oriach JL, Navarro-Arce I, Iglesias P, Galán-Ortega M, Rubio-Navarro M, et al. (2013) Tratamiento preoperatorio con levosimendan para paciente con disfuncion ventricular derecha previa a cirugia de sustitucion valvular. Rev Esp Cardiol 66: 999 1000.

86. Morelli A, Teboul JL, Maggiore SM, Vieillard-Baron A, Rocco M, et al. (2006) Effects of levosimendan on right ventricular afterload in patients with acute respiratory distress syndrome: a pilot study. Crit Care Med 34: 2287-2293. [Crossref]

87. Levin R, Degrange M, Del Mazo C, Tanus E, Porcile R (2012) Preoperative levosimendan decreases mortality and the development of low cardiac output in highrisk patients with severe left ventricular dysfunction undergoing coronary artery bypass grafting with cardiopulmonary bypass. Exp Clin Cardiol 17: 125-130. [Crossref]

88. Eriksson HI, Jalonen JR, Heikkinen LO, Kivikko M, Laine M, et al. (2009) Levosimendan facilitates weaning from cardiopulmonary bypass in patients undergoing coronary artery bypass grafting with impaired left ventricular function. Ann Thorac Surg 87: 448-454. [Crossref]

89. Zangrillo A, Biondi-Zoccai G, Mizzi A, Bruno G, Bigrami E, et al. (2009) Levosimendan reduces cardiac troponin release after cardiac surgery: A meta-analysis of randomized controlled studies. J Cardiothorac Vasc Anesth 23: 474-478. [Crossref]

90. Parissis JT, Adamopoulos S, Antoniades C, Kostakis G, Rigas A, et al. (2004) Effects of levosimendan on circulating proinflammatory cytokynes and soluble apoptosis mediators in patients with decompensated advanced heart failure. Am J Cardiol 93: 1309-1312. [Crossref]

91. Cohen-Solal A, Logeart D, Huang B, Cai D, Nieminen MS, et al. (2009) Lowered B-type natriuretic peptide in response to levosimendan or dobutamine treatment is associated with improved survival in patients with severe acutely decompensated heart failure. J Am Coll Cardiol 53: 2343-2348. [Crossref]

92. Haikala H, Pollesello P (2000) Calcium sensitivity enhancers. IDrugs 3: 1199-1205. [Crossref]

93. Kopustinskiene DM, Pollesello P, Saris NE (2001) Levosimendan is a mitochondria K(ATP) channel opener. Eur J Pharmacol 428: 311-314. [Crossref]

94. Kersten JR1, Montgomery MW, Pagel PS, Warltier DC (2000) Levosimendan, a new positive inotropic drug, decreases myocardial infarct size via activation of K (ATP) channels. Anesth Analg 90: 5-11. [Crossref]

95. Harrison RW, Hasselblad V, Mehta RH, Levin R, Harrington RA, et al. (2013) Effect of levosimendan on survival and adverse events after cardiac surgery: a meta-analysis. $J$ Cardiothorac Vasc Anesth 27: 1224-1232. [Crossref]

96. Maharaj R, Metaxa V (2011) Levosimendan and mortality after coronary revascularisation: a meta-analysis of randomised controlled trials. Crit Care 15: R140. [Crossref]

97. Rubio-Regidor M, Pérez-Vela JL, Escribá-Bárcena A, Corres-Peiretti MA, RenesCarreño E, et al. (2007) Neurological complications in cardiac surgery post-operative period. Med Intensiva 31: 241-250. [Crossref]

98. Mahanna EP, Blumenthal JA, White WD, Croughwell ND, Clancy CP, et al. (1996) Defining neuropsychological dysfunction after coronary artery bypass grafting. Ann Thorac Surg 61: 1342-1347. [Crossref]

99. Thakar CV, Worley S, Arrigain S, Yared JP, Paganini EP (2005) Influence of renal dysfunction on mortality after cardiac surgery: modifying effect of preoperative renal function. Kidney Int 67: 1112-1119. [Crossref]

100. Górriz Teruel JL, Beltrán Catalán S (2011) Assessment of renal function, iatrogenic hyperkalemia and acute renal dysfunction in cardiology. Contrast-induced nephropathy. Rev Esp Cardiol 64: 1182-1192. [Crossref]

101. Niu ZZ, Wu SM, Sun WY, Hou WM, Chi YF (2014) Perioperative levosimendan therapy is associated with a lower incidence of acute kidney injury after cardiac surgery: a meta-analysis. J Cardiovasc Pharmacol 63: 107-112. [Crossref]

Copyright: (C2015 Escalona-Belmonte Juan J. This is an open-access article distributed under the terms of the Creative Commons Attribution License, which permits unrestricted use, distribution, and reproduction in any medium, provided the original author and source are credited. 